\author{
Људмила Поповић \\ Филолошки факултет Универзитета у Београду \\ ljudmila.popovic@fil.bg.ac.rs \\ Ljudmila Popović \\ University of Belgrade, Faculty of Philology \\ ljudmila.popovic@fil.bg.ac.rs
}

\title{
КОМУНИКАТИВНЕ ФОРМУЛЕ У СРПСКОМ ЈЕЗИКУ: ПИТАЬА ТИПОЛОГИЈЕ И АНАЛИЗЕ
}

\section{COMMUNICATIVE FORMULAE IN SERBIAN: PROBLEMS OF TYPOLOGY AND ANALYSIS}

Проблематика тзв. комуникативних или дискурзивних формула у српском језику раније није привлачила посебну пажњу истраживача. У овом раду комуникативне формуле се посматрају као саставни део комуникативних фразеологизованих конструкција, где спадају и синтаксички фразеологизми (фраземи). Уводе се појмови комуникативног алгоритма и прагматичке парадигме. Комуникативне формуле се тумаче као конструкције у којима је постигнут највиши степен прагматикализације. Анализирају се сличности и разлике између процеса прагматикализације и граматикализације. Издвајају се основни типови комуникативних формула у српском језику и разматра се њихова прагматичка структура, с посебним акцентом на формули $M a$ даj!, као и формулама за прихватање и одбијање, које се пореде са аналогним формулама у руском језику.

Кључне речи: комуникативне формуле, синтаксички фразеологизми (фраземе), прагматикализација, прагматичка парадигма, српски језик.

The analysis of the so-called communicative or discursive (speech) formulae in the Serbian language has not previously attracted special attention of researchers. In this article, communicative formulae are considered as an integral part of communicative phraseological units, which include syntactic phraseological constructions (phrasemes) as well. The concepts of communicative algorithm and pragmatic paradigm are introduced. Communicative formulae are interpreted as constructions with the highest degree of pragmaticalization. The similarities and differences between the process of pragmaticalization and grammaticalization are analyzed. The main types of the Serbian communicative formulae are singled out and their pragmatical structure is considered, with special emphasis on the Ma daj!, as well as confirmation and refusal formulae, which are compared with similar formulae in Russian.

Key words: communicative (speech) formulae, syntactic phaseologisms (phrasemes), pragmaticalization, pragmatic paradigm, Serbian language. 


\section{1. Увод}

Као што је познато, алгоритам је методолошки скуп корака који се могу користити у циљу обрачунавања, решавања задатака и проналажења адекватних решења. Притом алгоритам не подразумева конкретни поступак већ првенствено методу којом се треба руководити приликом решавања одређеног типа проблема. Да би се постигао зацртани циљ, примењује се адекватан алгоритам.

Комуникативни вербални чин, без обзира на то да ли се ради о дијалогу или наративу, такође је заснован на коришћењу алгоритама. На ту чињеницу први су скренули пажњу структуралисти трагајући за алгоритмима конструисања текстова у оквиру одређеног жанра. Тако је Бахтин издвајао стабилне структурне типове комуникативне делатности, сегментоване на исказе, које је посматрао као гооворне жанрове (Бахтин 1979: 237). Говорни жанрови одговарају типизованим комуникативним ситуацијама у којима се користе типизовани обрасци исказа у оквиру типских тема и типских односа реченог према ванјезичкој стварности.

Теорија говорних чинова донела је појачано интересовање за конкретна средства реализације одређених комуникативних алгоритама — говорних чинова (Austin 1962; Searl 1969). Говорни чинови представљају методолошке скупове корака помоћу којих говорник комуникативно делује остварујући своју намеру са циљем утицаја на саговорника, који по први пут у језичкој анализи постаје равноправни коучесник у конституисању исказа. Том приликом говорник путем употребе перформативних глагола (йозивам, обећавам, нудим, захваљујем итд.) или перформативних формула (Добро доили! Часна реч! Изволийе! Хвала лейо!) моделује саговорников

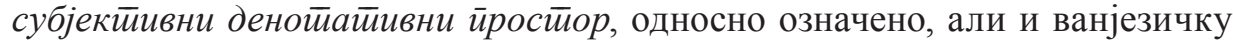

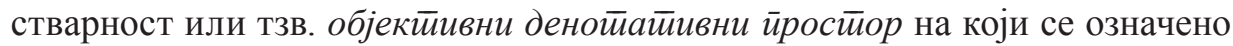
односи (Поповић 2005: 992-993). Перформативне формуле притом представљају тип лексичко-семантичких перформатива, који су у мањој или већој мери идиоматизовани, те се њихова илокутивна функција не може извести полазећи од појединих саставних елемената, већ на основу препознатљивог облика који се перципира као целина (Поповић 2005: 1002-1003).

Предмет овог рада, међутим, не представљају перформативне формуле, већ конструкције којима се комуникативно делује на други начин. У питању су комуникативне формуле којима се усмерава и организује комуникација, преноси говорников став према порукама других учесника, као и према самим учесницима, и генерално олакшава ток интеракције. То су устаљени искази, попут: Немој ми рећи! Како тио сад! Ма щйй кажещu! Нема йроблема; Кажи драг̈ичка! и сл., чији се садржај и функције не могу извести путем семантизације саставних елемената већ се декодирају у оквиру препознатљивог алгоритма. Комуникайивне формуле иредсииављају устиаљене комбинације самостиалних и йомоћних речи са наг̈лащеном ексйресивно-дискурзивном функиијом које се иеериийирају некомйозиционално, 


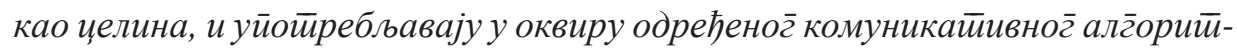

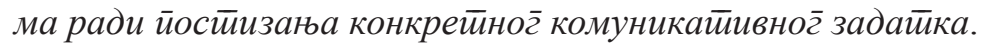

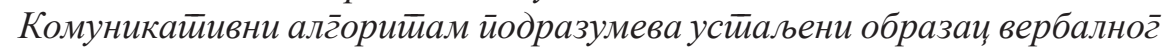
и невербалног йонащањ а у складу са којим се бирају унайред задайа средстива која йо говорниковом мищлень, ирилагоођеном устиаљеној ирракси у од-

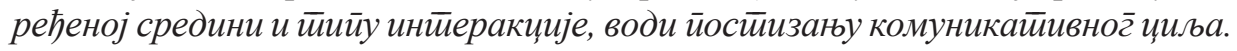

Како би се објаснио аутентичан приступ анализи комуникативних

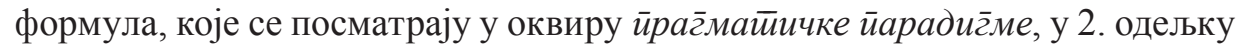
биће указано на особености перформативних конструкција, објашњено каква су њихова диференцијална обележја и увешће се појам перформативне парадигме, у чијим оквирима се издвајају перформативне формуле. Перформативна парадигма у овом раду се анализира полазећи од терминологије којом се описује синтаксичка парадигма реченице, те се уводе појмови екстерених иирансформација и иниеерних модификащија исказа који чине једну перформативну парадигму. Биће истакнуто како су перформативне трансформације и модификације пропраћене йовећањем или смањењем илокуииивног̄ найона исказа. Притом се перформативне формуле посматрају као редуковане варијанте пуних или експлицитних перформативних исказа.

Даље у раду биће показно да су комуникативне формуле организоване налик перформативним формулама и представљау редуковано језгро

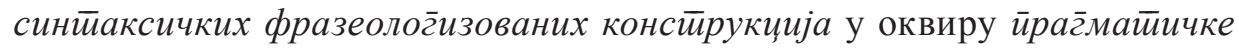
йарадиг̄ме.

Истраживање се ослања на методолошке поступке који се у савременој лингвистици користе за анализу комуникативних фразеологизама - како у оквиру традиционалног описа фразеологизованих синтаксичких структура (Шведова 1980: 382-386) тако и граматике конструкција (Lakoff 1987; Kay 1988; Fillmore, Kay 1993; 1999; Fried, Ostman 2004; Croft 2002 и др.) или модела описа језика који је заснован на његовој употреби, тзв. usage-based model (Langacker 1987; 1988). Посебан акценат је стављен на структуралистички приступ опису фразема Лидије Иорданске и Игора Мељчука (Иорданская, Мельчук 2007), а диференцијална обележја комуникативних формула се одређују с ослонцем на методе које примењује у својим истраживањима Јекатерина Рахилина (Рахилина 2010, 2019).

У даљем излагању (в. одељак 4) уследиће осврт на појам йраг̄майикализиије, која се пореди са сличним процесом граматикализације у језику. Истичу се разлике између оба процеса и на конкретном примеру се тумачи појам прагматичке парадигме. Следи осврт на прагматичку структурну шему исказа (5. одељак).

У циљу илустрације аналитичког поступка који је заснован на издвајању прагматичке парадигме, у 6. одељку анализира се полифункционална формула Ma daj!, притом се поједине њене комуникативне функције тумаче у поређењу с аналогним функцијама адекватних комуникативних формула у руском језику.

Затим се разматрају алгоритми сходно с којим се користе комуника- 
ииивне формуле иррихвайања и одбијања у српском језику и показује да је избор одређене формуле, између осталог, условљен тиме ко је врщилаи радње, а ко је њен бенефииијар.

На крају истраживања (в. 7. одељак) нуди се сажет преглед основних типова комуникативних формула у српском језику, који се издвајају из функционалне перспективе. Понуђена типологија је пропраћена освртом на основне кластере комуникативних формула у руском језику.

\section{2. Прагматичка структура исказа и појам перформативне парадигме}

Прагматичка структура говорног чина обухвата парадигму исказа који су уједињени око централне компоненте - перформативног глагола. У зависности од валентности перформативног глагола, парадигма може садржати мање или више исказа од којих ће један представљати ексиилицитину иеррформаииивну формулу (Поповић 2005: 998-999), која у синтаксичкој равни представља конструкцију са попуњеним актантним позицијама перформативног глагола. Нпр. исказ Информищемо вас о сииању на йуиевима садржи прототипични перформатив типа асертива (информищемо) и два

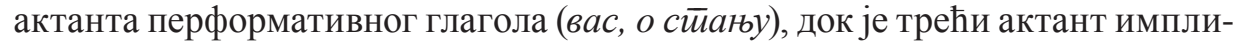
цитно присутан у конструкцији, односно, исказан је синтетички — помоћу личног наставка глагола (-мо).

Истицање говорног лица путем употребе личне заменице у перформативном исказу у српском језику увек је прагматички обележено и уобичајено трансформише илокутивни потенцијал једног типа говорног чина у други. Рецимо, у наведеном примеру експликација личне заменице $м и$ трансформише исказ из говорног чина типа асертива у директив, попут оних који су уобичајени за говорни чин понуде у дикурсу рекламе, уп.:

(1) Информищемо вас о сйағу на йуиеевима. (асертив, најава, саопштење);

(2) Ми информищемо вас о стиағу на йуйевима. (директив, понуда, реклама).

Исти исказ без личне заменице вас (Информищемо о стиағу на йуйевимa), или самог перформативног глагола, представља лаконичнију најаву, чиме је одговарајуће појачан његов илокутивни напон, уп.: Сйање на $\bar{u} y$ йевима (Studio B).

Сви наведени искази заједно чине иеерформайивну йарадиг̄му једног исказа:

(3) Ми информищемо вас о стиану на йуиеевима.

Информищемо вас о сииану на иууиевима.

Информищемо о сийағу на йуиевима.

Информищемо вас.

Информищемо.

Сйање на йуиеввима. 
Слично синтаксичкој парадигми (Шведова 1980: 86), перформативна парадигма садржи исказе који ступају у односе екстерне трансформације и интерне модификације са другим исказима.

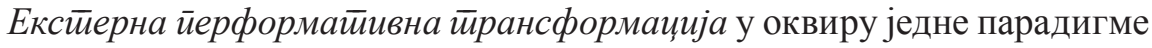
обухвата односе између исказа са различитом илокутивном функцијом, који припадају различитим типовима говорних чинова. Такви односи воде претварању говорног чина једног типа у чин другог типа (као у наведеном примеру у којем се асертив трансформише у директив услед додавања исказу личне заменице $м и$ ).

Иниеерна иерформайивна модификација у оквиру перформативне парадигме представља однос између исказа са истом или сличном илокутивном функцијом унутар једног типа говорног чина. Такви искази се по правилу разликују према јачем или слабијем илокутивном напону у оквиру једне илокутивне функције. На пример, искази Уйозоравамо на ойасносй !

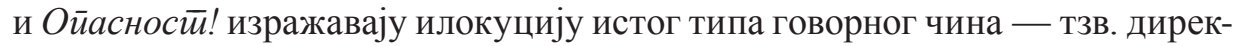
тива, али исказ са елидираним перформативним глаголом поседује већи илокутивни напон, због своје лаконичности јаче делује на реципијента.

Перформативне модификације унутар истог типа говорних чинова најчешће су засноване на елипси - изостављању једног или више актаната перформативног глагола, односно на изостављању самог перформативног глагола који прелази у тзв. имплицитна перформативна средства и лако се очитава у дубинској равни.

\section{3. Комуникативни фразеологизми и методолошки приступи њиховој анализи}

Временом научници су дошли до закључка да је алгоритам састављања фразе заснован како на семантичким принципима тако и на прагматичким. Уколико је Јуриј Апресјан констатовао да је према основном семантичком закону који регулише исправно разумевање текста од стране примаоца декодирање поруке засновано на принципу редундантних сема, тј. оних које се најчешће јављају у полисемичним структурама речи у исказу (Апресян 1995: 13), когнитивни лингвисти су приметили да се приликом декодирања мора узети у обзир и тзв. експеријенцијални контекст (в. о томе више у: Поповић 2017), који је заснован на алгоритму похрањеном у оквиру одговарајуће асоцијативне мреже у облику одређеног фрејма или сценарија.

Једно остаје несумњиво, уколико машина приликом декодирања исказа слаже елементе у складу са задатим сетом правила која налажу препознавање најучесталијих сема у структури његових саставних компоненти, човек се приликом комуникације руководи првенствено алгоритмима, заснованим на механизмима који у коначној инстанци воде постизању комуникативног циља, праћеног физиолошким осећањем задовољства. Говорник непрестано у процесу комуникације моделира свој исказ у складу са реалном или претпостављеном реакцијом реципијента, прилагођава 
га контексту ситуације према устаљеном алгоритму који је формиран на бази сличних комуникативних искустава.

У зависности од типа комуникативне ситуације, говорник продукује свој исказ полазећи од циља који је неопходно постигнути, притом из понуђеног репертоара бира оне конструкције чији прагматички потенцијал, по његовом мишљењу, одговара одређеном типу комуникације, а руководи се првенствено прагматичким стратегијама које представљају унапред задати алгоритам.

Шта заправо одређује прагматичку ефикасност комуникативне формуле? Филозофија и лингвистика 20-21. века трагале су за одговором на то питање кроз проучавање говорних чинова, прагматичких максима, али и изражајног потенцијала конструкција које користимо у конверзацији као задате идиоматизоване обрасце. Као што користимо појмовне метафоре не обраћајући пажњу на њихову унутрашњу форму, која, међутим, одређује нашу рецепцију стварности (Lakoff, Johnson 1980), тако и прагматичка структура идиоматизоване конструкције одсликава одређени поглед на свет, који се може декодирати полазећи од унутрашње форме прагматичког центра око којег се формира парадигма исказа сличног комуникативног потенцијала. Циљ овог рада је да се образложи претпоставка о постојању прагматичке парадигме идиоматизоване конструкције. Као грађа за анализу послужиће примери из српског језика, од којих се неки разматрају у поређењу са сличним источнословенским.

У савременој лингвистици широко је заступљен приступ проучавању језика према којем се језичке структуре посматрају као производ устаљене лингвистичке праксе конструисања исказа (в. преглед когнитивнолингвистичких поставки таквог приступа у: Langlotz 2006; Рахилина 2010), што значи да говорник у свакодневној комуникацији веома често оперише већ спремним фразама које се актуелизују у складу са њиховом учесталошћу у говору. Број таквих унапред задатих исказа може да се упореди са бројем речи у језику, те оне не могу представљати периферну појаву у језику и заслужују да буду пажљиво испитане и систематизоване (Jackendoff 1995: 136).

Исказ се дакле посматра као скуп одређених полуфиналних производа, чијом комбинацијом долазимо до неопходне конструкције. Такав производ се свакако може раставити на елементе синтаксичке структуре, слично томе како се реч разлаже на морфеме. Међутим, као што не састављамо реч од морфема сваки пут кад желимо да је употребимо, већ је памтимо као целину, тако и синтаксичке структуре мање-више памтимо интегрално, мењајући варијабиле око одређеног језгра, које може да представља синтаксички центар конструкције (глагол) или прагматички центар исказа. Прагматички центар исказа не подудара се увек са синтаксичким центром реченице, заправо у његовој функцији често се јавља синсемантичка реч, попућ речце или везника.

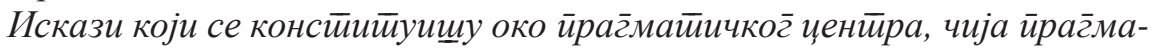

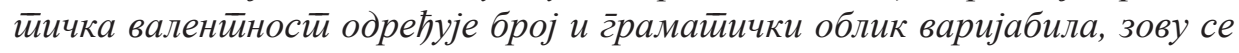


синйаксички фазеолог̄изми. Таква дефиниција је заснована на прагмалингвистичком приступу.

Структуралистичка дефиниција синтаксичког фразеологизма (фразема), коју је понудио Александар Мељчук, одређује га као комплекс X који се састоји од сегментних знакова $\mathrm{X} 1, \mathrm{X} 2, \ldots \mathrm{Xn}$, притом један од компонената комплекса $X$ (његово означено, означитељ или синтактика') не може да се представи помоћу одговарајућих компоненти знакова X1, X2, ... Xn, док две преостале компоненте знака могу бити представљене помоћу одговарајућих компоненти (Мельчук 2001: IV, 448). ${ }^{2}$

Мељчук такође предлаже четири стратегије описа синтаксичког фазеологизма, полазећи од којих је могуће описати све типове фразема (Мельчук 1968; Иорданская, Мельчук 2007). Размотрићемо их на одговарајућим примерима из српског језика.

1. Језичка јединица која је подвргунта идиоматизацији, може бити

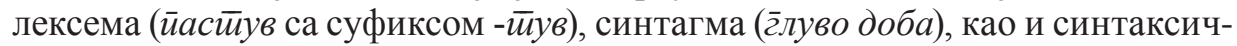
ка конструкција. Као пример потоње у српском језику може да се наведе исказ Ти ћещ $\partial а$ ми кажещu!, чији се прагматички потенцијал може моделирати у оквиру различитих типова интонационих конструкција. Једна варијанта се реализује, на пример, у комуникативној ситуацији испитивања на школском часу (наставник указује на одређеног ученика и позива га да одговори на питање), док се друга реализује као иронични исказ, у ситуацији подсмевања или ругања коме. Друга варијанта искључује чисто композиционалну интерпретацију исказа и у целини је заснована на њеној идиоматизованој рецепцији. Покущај комйозиционалне иниеериретиаиије

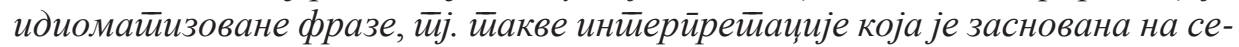

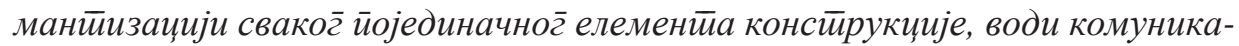
ииивном иромащају.

2. Посматра се заступљеност у идиоматизацији прагматичких фактора у вези са комуникативном ситуацијом у којој се устаљено користи од-

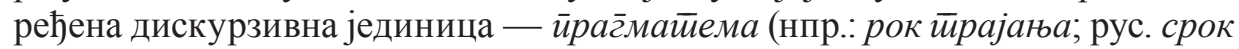
годности (букв. 'рок исправности'), укр. иеермін зберігання (букв. 'рок чувања'), енгл. best before (букв. 'најбоље је пре' и сл.) наспрам одсуства таквих приликом употребе семантичких фразеологизама, нпр. рус. бить ба-

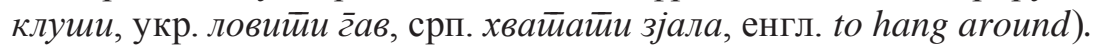

3. Издваја се компонента језичког знака која је подвргнута идиоматизацији. То може бити означено (нпр. хвайайи зјала), означитељ (нпр. су-

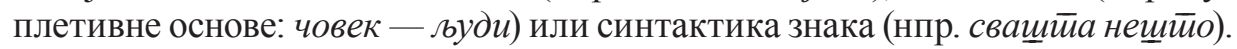

1 Осим означеног и означитеља, Мељчук издваја и трећи елемент знака - синтактику (Мельчук 2001)

2 «Комплекс X, образованный из сегментных знаков X1, X2, ... Хn, называется фраземой, если, по крайней мере, один из трех компонентов этого комплекса X (т. е. его означаемое, обозначающее или синтактика) не представим в терминах соответствующих компонентов знаков X1, X2, .. Xn, в то время как два других его компонента представимы в терминах соответствующих знаков X1, X2, ... Xn» (Мельчук 2001: IV, 448). 
4. Одређује се степен идиоматизације, у складу са којим фраземи се деле на потпуне или идиоме (очит̄айи буквицу), полуфраземе или колока-

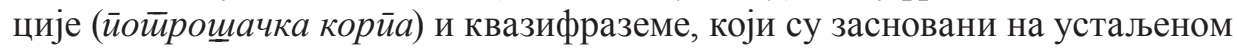

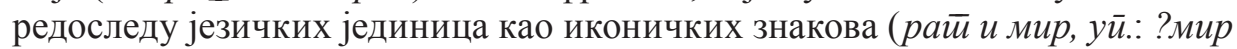

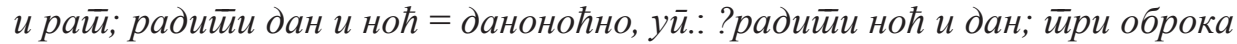
дневно - доручак, ручак, вечера, уп.: ?вечера, ручак, доручак).

Синӣаксички фразеолог̄изми су зайраво резулйай својеврсне лексика-

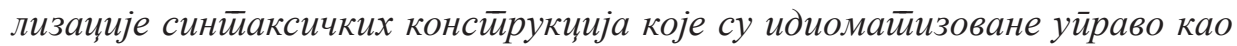
консйрукиије, а не услед семанйичког̄ йуњења конкрейних речи. Оне имају устаљену шему према којој су грађене — константа + променљива (X) или променљиве (X, Y, Q) - у зависности од валентности константе. У функцији константе могу се јавити везници (Кад је $\mathrm{X}\left[\mathrm{N}_{1}\right]$, нек је $\mathrm{X} / \mathrm{Y}\left[\mathrm{N}_{1}\right]$ !), пред-

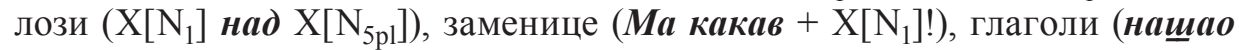
$\mathrm{X}[\mathrm{cop}]+\mathrm{Y}[\mathrm{Pron}]+\boldsymbol{\partial} \boldsymbol{a}\left[\mathrm{V}_{\text {fin }}\right]$ !) и друге речи. У функцији променљивих наступају пунозначне или функционалне речи, односно предлошко-падежне конструкције или синтагме (нпр.: Кад је бал, нек је бал!, Кад је фудбал, нек је фудбал! Кад је бал, нек је маскенбал! итд.; иесма над йесмама; исииина над исииинама итд.; Ма какав рођендан! Ма какав дечко! итд.; Нашао је ког̄а да иийиа! Нащао си коме да се йоверищu! Намао је г̄де да йаркира! итд.).

Одлике синтаксичких фразеологизама су: устаљени ред речи, одређени граматички облици пунозначних речи, строго одређени регистар помоћних речи, постојање лексичких варијабила или променљивих које пуне шему, као и прагматичке трансформације.

Синйаксички фразеолог̄изми сйадају у комуникайивне јединице или комуникайивне фразеолог̄изме, у складу с дефиницијом Т. М. Николајеве (Николаева 1985: 112), с тим што је појам комуникативног фразеологизма шири. К. В. Фомина (Фомина 2000: 7) сматра да синтаксички фразеологизам представља подтип комуникативног фразеологизма, где спадају и комуникативне (фразеологизоване) формуле (нпр.: Шӣа да се ради! Ма није ваљља!) и колоквијални елементи у функцији узвика или партикула (нпр.

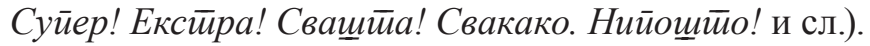

Табела 1

Комуникативни фразеологизми

\begin{tabular}{|c|c|c|}
\hline Тип & Структура & Пример \\
\hline $\begin{array}{l}\text { синтаксички } \\
\text { фразеологизам }\end{array}$ & $\begin{array}{l}\text { некомпозиционална конструкција } \\
\text { (константа + променљиве) }\end{array}$ & $\begin{array}{l}\text { Ма какав + } \mathrm{X}\left[\mathrm{N}_{1}\right] ! \\
\text { Ма какав одмор! }\end{array}$ \\
\hline $\begin{array}{l}\text { комуникативна } \\
\text { формула }\end{array}$ & $\begin{array}{l}\text { некомпозиционална конструкција } \\
\text { без променљивих }\end{array}$ & Ма каквих! \\
\hline колоквијални елемент & Реч & Сващй̄̄a! \\
\hline
\end{tabular}

Синтаксички фразеологизми и комуникативне формуле су вишекомпонентне, док је трећи тип (колоквијални узвици) заступљен једнокомпонентним изразом, те неће представљати предмет описа у овом раду. 
Основна разлика између конструкција и формула састоји се у томе да формуле не садрже варијабиле. Важна разлика постоји и на семиотич-

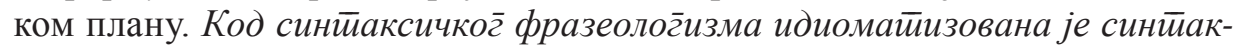

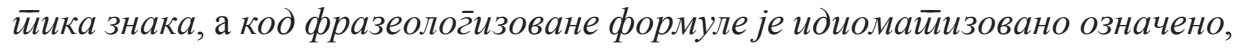
које се може означити и на други начин, нпр.:

(4) Како да не кажем! Како да не йомог̈нем! Како да се не ьуйим! итд.

(5) - А онда је мрмой зайаковао чоколаду у фолију.

- Да, да, како да не! (Реклама)

(6) „Усрећи ћемо“... како да не! (Како Јеца каже, 06.06.2012)

У примеру (4) синтаксички фразеологизам са константом Како да не и променљивом коју попуњава лично-временски глаголски облик (тип фразема Како да не $+\mathrm{V}_{\text {fin }}$ ) врши комуникативну функцију уверавања саговорника да говорно лице не може поступити друкчије у ситуацији која је настала. Конструкција се декодира некомпозиционално јер је идиоматизован одређени редослед речи (уп. са исказом Да не кажем како?, који се тумачи композиционално). У примерима (5) и (6) наведене су комуникативне формуле чији се садржај може пренети и помоћу мање експресивних исказа: (5) Не верујем; (6) Пог̄рещно је.

За исправно тумачење комуникативне формуле неопходан је увид у прагматички контекст ситуације. У наведеном примеру из популарног рекламног спота (5), израз лица жене која одговара на претходни исказ, њене подигнуте обрве и благо указивање главом на саговорника (гест који се може интерпретирати као питање 'Јесте ли чули ову глупост?') сведоче о иронији. У примеру (6) на иронично порицање упућује погрешно написан облик футура у исказу на који се реагује комуникативном формулом. И у овом случају контекст је ситуативан јер одашиља ка одређеном ортографском правилу.

Јекатерина Рахилина и њен тим, који ради на састављању електронске базе комуникативних фразеологизованих конструкција у руском језику, тзв. Руског консӣрукіиикона, у значењу комуникативне формуле користе термин дискурзивна формулаз (Рахилина 2019).

Сагласно њеном приступу, комуникативне формуле одређују следећа диференцијална обележја:

- некомпозиционалност;

- висока фреквентност;

3 Е. Рахилина (2019) наводи да је Чарлс Филмор, још 1984, први скренуо пажњу на дискурзивне формуле у енглеском језику поредећи их са сличним изразима у другим језицима и претпоставља да се управо из тог интересовања развила његова теорија граматике конструкција, коју је изложио у антологијском раду из 1988 (Fillmore 1988). Поређење дискурзивних формула у разним језицима заиста је инспиративно, уп.: (енгл.) You should talk! (срп.) Ма немој! (рус.) Кто бы говорил! (укр.) Мовчав би вже!; (енгл.) Соте on! (срп.) Ма даj! (рус.) Да ну! (укр.) Та щцо иии!; (енгл.) No way! (срп.) Нема щансе! (рус.) Да ни в жизнь! (укр.) Та нізащо! и сл. 
- устаљени интонациони оквир;

- пропратна гестикулација;

- варијативност (најчешће се састоје од помоћних речи, партикула, дискурсних маркера и сл.);

- спадају у међупростор између граматике и лексике (Ibid.).

По мишљењу истраживача који сарађују у оквиру наведеног пројекта, руски језик садржи неколико стотина дискурзивних формула, а уколико се узму у обзир и њихове варијанте, број таквих идиома исноси око хиљаду. С обзиром на чињеницу да је за одређивање овог броја коришћено око 500 драмских текстова 19-20. века (Ibid.), било би интересантно одредити на сличном корпусу приближан број дискурзивних формула које функционишу у српском језику, што препуштамо будућим истраживањима.

\section{4. Прагматикализација vs граматикализација и прагматичка парадигма исказа}

Комуникативни фразеологизми су резултат процеса у језику који се могу уопштено одредити појмом прагматикализације. Праг̄матиикализа-

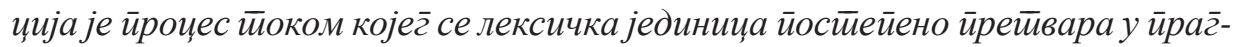

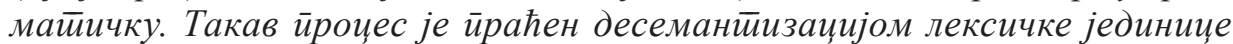
и комуникайивном сиечијализаиијом констирукиије у чији сасйав она улази. Рецимо, у конструкцији Немој ми рећи! семантика глагола је потиснута, док се развија комуникативна функција изражавања чуђења коју конструкција релизује као целина. Стога, као што је било истакнуто и раније у овом раду, комуникативни фразеологизам није композиционалан.

Слично граматикализацији, прагматикализација је заснована на дефокусирању границе. Граматикализација се традиционално посматра као дијахронијски процес и тумачи као йрейварање лексичке јединице у гррама$\bar{u} и ч к y$ (Meillet 1912). У савременом тумачењу граматикализација је процес који води стварању нове граматичке категорије или замени старих средстава изражавања граматичког значења новим (Kuteva, Heine 2012: 161). Под

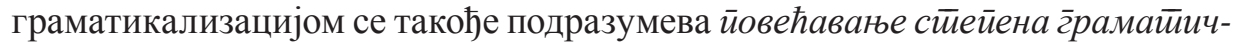
ностии језичке јединице (Kuryłowicz 1965: 55-71; Brinton, Traugot 2005: 99).

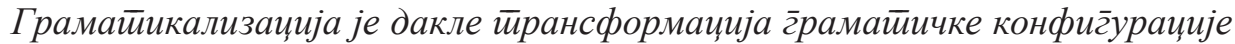
језичке јединище, њеног̄ облика и г̄рамайичких функиија.

Тако схваћеној граматикализацији је налик йраг̃майикализација, која

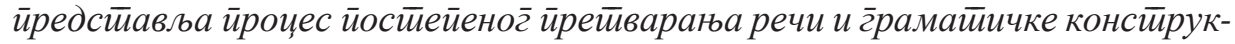
иије у йраг̈майичку јединииу, у смислу йоииискивања њене семанииике наущйрб развоја одређених комуникайивних функиија. Када је у питању конструкција, ради се о трансформацији њене конфигурације у правцу синтагматског везивања саставних елемената и претварања рецесивног значења конструкције, тј. таквог које се може декодирати само у одређеном контексту, у доминантно, које више не зависи од подршке контекста. Дакле, мењају се комуникативне функције конструкције које на крају процеса прагмати- 
кализације престају да зависе од лексичке и граматичке семантике њених саставних компоненти. Десеманӣизација језичке јединище йод уйицајем дискурса, њена йосиеиеиена идиомайизаџија, ираћена развојем нових кому-

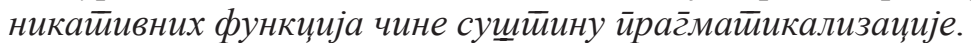

Као што у процесу граматикализације семантика језичке јединице одређује граматичку функцију коју та јединица развија а након завршеног процеса граматикализације може се очитати као „унутрашња форма“ граматичког елемента, тако и семантика одређене компоненте у саставу граматичке конструкције одређује правац њене прагматикализације, а временом, по завршетку процеса прагматикализације, може се очитати као „унутрашња форма“ фразеологизоване конструкције. Рецимо, у процесу

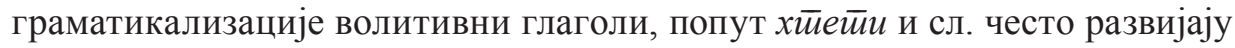
футурално значење и постају клитичка средства за формирање аналитич-

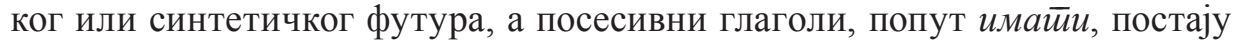
аналитички показатељ перфекта, што се може очитати у унутрашњој фор-

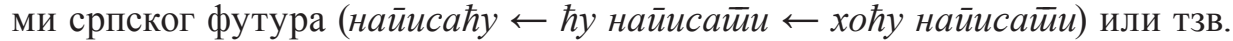
посесивног перфекта (имам найисано два рада чимам два найисана рада Ł имам два рада које сам найисао).

Слични процеси одређују и суштину прагматикализације. Рецимо, у конструкцијама са компонентом дај у српском језику долази до фразеологизације на основу трансформације глагола дайи са предметним аргу-

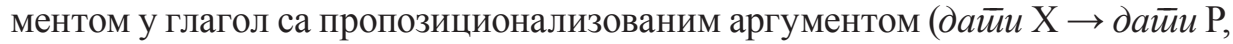

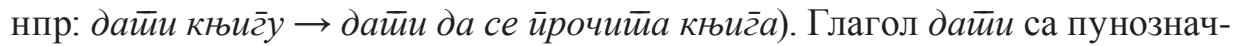
ним глаголом на позицији аргумента временом развија модализовано значење, које касније одређује трансформацију његовог облика императива у речцу императивне семантике дaj = хајде. Тим путем долази до прагматикализације овог облика, тј. потискивања његове семантике на рачун нове дискурзивне функције, уп.:

(7) Дај йомози нам да и ми дођемо йамо (Данас, 22.03.2019);

(8) Дај йољуби ме (Ј. Томашевић) и сл.

У комбинацији са речцом ма, која се користи за експресивно јачање исказа, а са акцентом ма̂, поред истицања, исказује и чуђење (Skok 1972: 343), десемантизовани глаголски облик дај формира константу фразеологизованих конструкција са отвореном позицијом за променљиву у облику императива пунозначног глагола (Ма дај, йресйани! Ма дај, заборави! и сл.), да би у крајњој фази прагматикализације функционисао као комуникативна формула $M a$ даj!, чије функције биће детаљно анализиране даље у овом раду.

Све варијанте фразеологизованих конструкција с базном компонентом дај можемо размотрити у оквиру прагматичке парадигме, у којој су заступљени искази различитог степена прагматикализације. Уједно на овом примеру можемо пратити формирање фразеологизоване конструкције дијахронијски — од реченице коју одређуе синтаксичка валентност глагола 
дайи до исказа који представља комуникативну целину коју држи на окупу прагматичка валентност сложене партикуле ма даj:

(9) Дај донеси књигуу, молим ӣе!

Ма дај йомози, молим йе!

Ма дај, молим ӣе!

Ma $\partial a j !$

Ma daaaj!

Граматикализација поседује низ дискурзивних, структурних и когнитивних дистинктивних обележја (в. Kuteva, Heine 2012: 162; Bybee 2003: 146), која се могу пресликати и на прагматикализацију, уп.:

1. Долази до дикурзивне генерализације, тј. устаљеног коришћења конструкције у новом контексту, које води развоју нових комуникативних функција;

2. Дешава се десемантизација, која подразумева промену и губитак лексичког значења;

3. Долази до промене морфосинтаксичке парадигме - њене редукције (нпр. глагол дайu редукује своју парадигму до облика 2. л. једн. императива и постепено се трансформише у речцу;

4. Мења се фонетска супстанца језичке јединице која постаје константа исказа, нпр. општа заменица ма какав/ма каква/ма какво/ма какви/ма какве/ма каква постепено се фонетски редукује у функцији комуникативне формуле, уп.: Ма какав мајст̄ор! Ма каквих! $\rightarrow$ Ма каки мајсі̄ор! Ма каки! ${ }^{4}$

5. Истовремено се дешавају промене у психологији говорника који се навикавају на нову конструкцију и ослобађају од навике да је користе семантизујући саставне елементе, нпр.: Немој ми рећи!

Оно што битно разликује прагматикализацију од граматикализације је чињеница да услед граматикализације долази до пораста степена граматичности језичке јединице, што значи да она постаје редундантна и аутоматски се користи у једном значењу, док услед прагматикализације јединица постаје комуникативно полифункционална, а њена конкретна употреба у целини зависи од алгоритма комуникативне ситуације и говорникове комуникативне стратегије.

Прагматичка вредност комуникативног фразеологизма у појединим случајевима подразумева и перформативну вредност (нпр. Камо среће!'’елео бих'), али је такво перформативно значење додатно експресивно обележено. Изразита експресивна обојеност издваја комуникативне идиоме у односу на перформативне формуле, које су у том погледу необележене.

4 Примере таквог типа можемо наћи у бројним драмским текстовима, уп.: ЦМИЉА: А у ствари је био лимар...

ИКОНИЈА: Ма каки лимар, није ни лимар, и то је било само фиктивно!

МАНОЈЛО: Све ми се зацрнело пред очима!

(љ. Симовић)

ТАНАСКО: Ма каки зацрнело, погледај како сија! (љ. Симовић) 


\section{5. Прагматичка структурна шема исказа}

Као што се синтаксичке структурне шеме реченице разликују од језика до језика, тако се и прагматичке структурне шеме исказа разликују формирајући прагматички потенцијал одређеног језика.

Уколико ширу структурну шему реченице формира глагол у предикату и његови синтаксички актанти, који чине реченицу синтаксички и информативно завршеном, прагматичку структурну шему синтаксичког фразеологизма одређује стабилна базна компонента - носилац илокутивног напона исказа, и прагматички условљене променљиве које чине исказ комуникативно успешним.

Полазећи од чињенице да променљиве у синтаксичком фразеологизму нису условљене синтаксичком валентношћу предиката већ својеврсном прагматичком валентношћу базне компоненте, можемо размотрити поједине прагматичке структурне шеме исказа у српском језику и упоредитии њихове основне моделе са аналогним моделима у другим словенским језицима.

Као што постоји синтаксичка парадигма реченице која је заснована на трансформативном потенцијалу њене дубинске семантичке структуре, тако постоји и прагматичка парадигма исказа, која је производ трансформације његове дубинске прагматичке структуре. Прагматичке трансформације синтаксичког фразеологизма зависе првенствено од таквих елемената као што су број прагматичких актаната базне компоненте, интонација, ред речи и сл.

Рецимо, практично неограничени деривативни потенцијал синтаксичких фразеологизама са речцом м $a$ и прилошким или придевским упитним заменицама у српском језику (Ма какав снег̄! 'Нема и неће бити снега'; $M a$ каквих куйила! 'Погрешан закључак, наравно да нисам купила'; Ма г̇де заборавила! 'Наравно да нисам заборавила' и сл.) можемо објаснити тиме што речца ма у српском језику служи као иницијални маркер реактивних адверзативних исказа. Са друге стране, упитне прилошке и придевске заменице, које такође улазе у овај тип синтаксичких фразеологизама, прагматички су засноване на негирању (недостатак информације у прагматичкој равни очитава се као негација постојања знања). Како епистемичка основа упитних речи у прагматичкој равни речи бива изостављена, илокуција негације у комплексу са реактивном адверзативном речцом мa чини наведене конструкције погодним за употребу у реактивним исказима којима се изражава неслагање или порицање.

У источнословенским језицима, на пример, конструкцијама овог типа одговарају оне које садрже адверзативну речцу $\partial a$ или $\bar{u} a$, којом уобичајено почиње реактивни исказ неслагања, као и упитне речи, уп.: (рус.) Да как же не заметить! 'Ма како нисам приметила!'; (укр.) Та звідки в мене громіi! 'Ма одакле ми новац!' итд.

Посебну пажњу привлаче они елементи базне прагматичке структуре, који су типични за сваки конкретни тип језика. На пример, у српском језику такав елемент представља прагмема генерализације, чији су показатељ 
речи са значењем уопштавања. Тако, универзални квантификатор све или општекатегоријално употребљена реч човек у српском језику обично улазе у базну компоненту синтаксичких фразеологизама којима се изражава негативна оцена информације у реактивном исказу, нпр.: Шӣа све човек може да измисли! 'Мислим да је ова информација лажна'. У источнословенским језицима такав специфичан прагматички показатељ представљају месне прилошке заменице или негација, нпр.: (укр.) Та куди $\overline{\bar{u} а м ~ з а б у л а ! ~}$ 'Ма каквих заборавила!' (рус.) Чего только здесь нет! 'Шта ту све има!' итд.

\section{6. Типови комуникативних формула и њихове функције}

Комуникативни фразеологизми се могу посматрати као иницијални

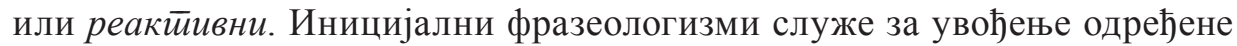
прагматеме у конверзацију док су реактивни - фраземе којима се реагује на саговорников исказ.

Још једна разлика између синтаксичких фразеологизама и комуникативних формула се састоји у томе што су формуле, йо ирравилу, искључиво реакйивне йрироде. Помоћу њих говорник реагује на ситуацију или исказе других учесника комуникације.

Иницијалних фразеологизованих формула има мало. У српском језику као пример такве можемо издвојити исказ Кажи драг̄uчка!, којим се најављује нови топик, те с тачке гледишта илокутивне функције ова формула могла би се одредити као експресивно обележен чин асертива. Посреди је најава информације која, по процени говорног лица, представља лепу вест, уп.:

(10) Она: Кажи драг̄ичка!

Ја: Драг̈ичка (са сӣрейњом у глласу).

Она: Куйила сам нове ичиееле које ми се слажу са комйлейом.

Ја: Којим комйлетиом?

Она: Уйс! Кажжи драг̄ичка јощи једном! (https://vukajlija.com/kazi-dragicka).

Овај исказ, којим се раније најављивао сваки трач (Кажи Драг̄ићка! $)$, временом је преосмишљен у формулу којом се најављују лепе вести, односно такве које по говорниковом мишљењу могу обрадовати саговорника. Као одговор на такву иницијалну формулу очекује се одговарајућа реактивна формула - Драг̄uчка!, која има искључиво фатичку функцију, тј. њоме се потврђује да је саговорник спреман да подржи конверзацију на предложену тему.

За разлику од наведене иницијалне формуле која је монофункционална, тј. може у сваком контексту реализовати само једну дискурзивну функцију, реактивне фразеологизоване формуле поседују прагматички потенцијал који се може остварити у зависности од конкретне ситуације у виду одређене комуникативне функције. Рецимо, формула $\boldsymbol{M a}$ даj! у српском језику

5 B.: (Nezavisne novine). 
може означавати, у зависности од контекста, порицање, чуђење или неслагање, нпр.:

(11) ЈОВАНА: Мног̄о сам г̄луйа била. Нищӣа нисам видела. Нищӣа нисам разумела.

Извини. Увек сам мог̄ла да осейим щитиа йи се дещива. Мног̄о смо вище

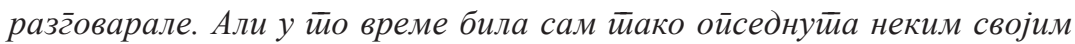
г̄луйосииима. Зайраво нису биле г̄луйостии, али ја нисам мог̈ла да се изборим.

МАРИНА: Ма дај, зар стиварно мислищ да йреба да ми се извињаващ сада због̄ $\bar{u} о \bar{z} a$ ? (Театрон 2016: 20).

(12) МАРИНА: Анийин муж.

ЈОВАНА: (циокирано) Ма даааааај! Па није он неки йолитиччар, он је... (Театрон 2016: 11).

(13) ЈОВАНА: А шит̄о не за Жарет̄а?

НИКА: Ма даaаaај! Па он ми је ко браӣ (Театрон 2016: 22).

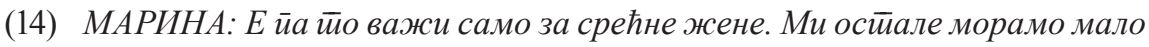
да инвестиирамо.

JOBAHA: Ма даaаaj! (Театрон 2016: 19).

У примеру (11) формула ма дај је употребљена у функцији порицања, а у примеру (12) - изражавања изненађења и чуђења, што потврђује дидаскалија „шокирано“. Емфатички акценат, који је изражен дуљењем вокала /a/, као и заокруженост интонационе конструкције, указују на појачани експресивни набој формуле. Пример (13) илуструје употребу реактивног исказа у функцији апсолутног порицања (емфатички акценат у овом случају не истиче само експресивну обележеност фразе већ и упућује на заступљеност девалоризације саговорниковог исказа, која би се могла друкчије исказати речима: „То су глупости!“). Исте елементе девалоризације налазимо и у примеру (14). Реактивна формула из тог примера могла би се заменити исказом „Апсолутно ниси у праву“ или њему сличним.

На примеру фразеологизоване формуле Мa даj! може се пратити процес који је она прошла приликом прагматикализације - од употребе у саставу синтаксичке фразеологизоване конструкције (у функцији константе - двокомпонентне речце, уз одговарајуће облике императива пунозначних глагола на позицији променљивих), преко самосталне реактивне комуникативне формуле, али уз ослонац на исказ чији садржај пориче, до потпуног прагматичког осамостаљења - функционисања у улози прагмеме, за чије значење није неопходан контекст ширег реактивног исказа. Уколико бисмо посматрали употребу ове формуле кроз време, могли бисмо видети да је такав пут хронолошки условљен, тј. комуникативни фразеологизам временом пролази пут од делимичне до потпуне прагматикализације6.

6 Рецимо, у драмским текстовима са краја 19. - почетка 20. века нисмо нашли ниједан пример употребе ове реактивне формуле, док у текстовима савремених писаца она је веома често заступљена, што потврђују наведени примери. 
Константа ма дај у саставу фразеологизоване конструкције може се наћи у функцији иницијалног типа исказа, док је потпуно прагматикализована могућа само у реактивном исказу, уп.:

(15) Ма дај, луйко, буди нечија! (Фрајле)

(16) Мa daаaаaj! (Театрон 2016: 19)

Константа ма дај се заправо састоји од двеју речци, од којих свака има самосталну употребу. Дај је речца императивне природе, која се користи у колоквијалном језику изофункционално речци хајде (нпр.: Дај йомози ми! Дај речи већ једном! Даај, не иррекидај ме! и сл.). Речца ма може да се користи за појачавање афирмативног или негираног исказа, нпр. Мa $\partial a ! / M a$ дaaa! Мa не! / Ма неее!, као и у саставу бројних комуникативних фразеологизама - како синтаксичких (који ће бити размотрени даље у тексту) тако и формула. У споју са речцом дај речца ма у синтаксичкој фразеологизованој конструкцији са императивом на позицији променљиве истиче директивну илокуцију подстицања на чин, нпр.:

(17) Ма дај обуции левисице (Данијел).

(18) Ма дај јави се већ једном!

У некомпозиционалној конструкцији ове две речце узајамно се допуњују претварајући се у комуникативни амалгалм, чије се значење, као што је било раније истакнуто, декодира у зависности од ситуативног контекста, али и с обзиром на интонационе карактеристике. Међузависност типа комуникативног фразеологизма (формула, конструкција), типа фразеологизованог исказа (реактивни, иницијални), комуникативне функције, унутар које се могу издвојити конкретне конотације, и основних интонационих и синтаксичких одлика формуле и конструкције могу се прегледно приказати помоћу табела (в. табеле 2 и 3).

Табела 2

\section{Комуникативна полифункционалност фразеологизоване формуле Ma daj!}

\begin{tabular}{|c|c|c|c|}
\hline $\begin{array}{c}\text { Тип } \\
\text { формуле }\end{array}$ & $\begin{array}{c}\text { Комуникативни } \\
\text { алгоритам }\end{array}$ & Прагматички контекст & Пример \\
\hline \multirow[t]{4}{*}{ Реактивна } & Изненађење & Изненађење + неверица & $\begin{array}{l}\text { - Украли су ми ауйо. — Ма дај! } \\
\text { [Не могуу да йоверујем у т̄о.] }\end{array}$ \\
\hline & & $\begin{array}{l}\text { Изненађење }+ \\
\text { разочарење }\end{array}$ & $\begin{array}{l}\text { - Покидала сам сандале. - Ма } \\
\text { дај! [Баш је неиријайна весй.] }\end{array}$ \\
\hline & Девалоризација & $\begin{array}{l}\text { Девалоризација понуде } \\
\text { и одбијање да се она } \\
\text { прихвати }\end{array}$ & $\begin{array}{l}\text { - Хајдемо у шетйьу. } \\
\text { — Ма дај! [Нећу. Уморан сам.] }\end{array}$ \\
\hline & & $\begin{array}{l}\text { Девалоризација } \\
\text { саговорника као } \\
\text { реакција на његово } \\
\text { понашање }\end{array}$ & $\begin{array}{l}\text { — Јеси ли ойрала судове? } \\
\text { - Нисам. } \\
\text { — Ма дај! [Никад их не } \\
\text { оиереши.] }\end{array}$ \\
\hline
\end{tabular}




\begin{tabular}{|c|c|c|c|}
\hline \multirow[t]{6}{*}{$\begin{array}{c}\text { Тип } \\
\text { формуле }\end{array}$} & $\begin{array}{c}\text { Комуникативни } \\
\text { алгоритам }\end{array}$ & Прагматички контекст & Пример \\
\hline & & $\begin{array}{l}\text { Девалоризација } \\
\text { говорног чина } \\
\text { (комплиментирања, } \\
\text { извињења и сл.) }\end{array}$ & $\begin{array}{l}\text { - Све си млађа и леимиа. } \\
\text { - Ма дај! [Немој да се ㅃалищ.].] }\end{array}$ \\
\hline & Резигнација & $\begin{array}{l}\text { Одустајање од чина } \\
\text { који саговорник } \\
\text { предлаже да изврше } \\
\text { заједно. }\end{array}$ & $\begin{array}{l}\text { — Ја ћу јом мало да радим, } \\
\text { хоћещ ли са мном? } \\
\text { - Ма дај! Одох ја кући. } \\
\text { [Ја вище не мог̄у да радим.] }\end{array}$ \\
\hline & Неслагање & $\begin{array}{l}\text { Неслагање са } \\
\text { саговорниковом } \\
\text { погрешном } \\
\text { претпоставком. }\end{array}$ & 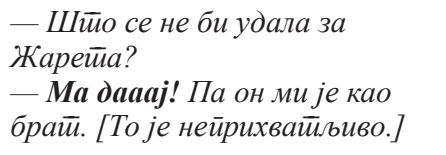 \\
\hline & & $\begin{array}{l}\text { Неслагање са } \\
\text { саговорниковим } \\
\text { мишљењем. }\end{array}$ & 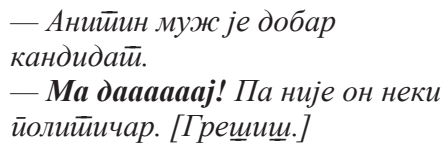 \\
\hline & & $\begin{array}{l}\text { Неслагање са } \\
\text { саговорниковим } \\
\text { логичким } \\
\text { конструисањем } \\
\text { закључка. }\end{array}$ & 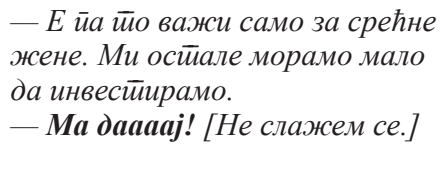 \\
\hline
\end{tabular}

Табела 3

Комуникативни потенцијал синтаксичких фразеологизама са константом ма дај.

\begin{tabular}{|c|c|c|c|}
\hline $\begin{array}{c}\text { Тип } \\
\text { исказа }\end{array}$ & $\begin{array}{l}\text { Комуникативни } \\
\text { алгоритам }\end{array}$ & Прагматички контекст & $\begin{array}{c}\text { Синтаксички израз } \\
\text { и пример }\end{array}$ \\
\hline & & & $\begin{array}{l}\text { Ма дај + X [Vimp] + [већ } \\
\text { једном]! }\end{array}$ \\
\hline \multirow[t]{2}{*}{$\begin{array}{l}\text { Иницијални } \\
\text { исказ }\end{array}$} & Подстицање & $\begin{array}{l}\text { Подстицање да } \\
\text { саговорник брже } \\
\text { оствари чин }\end{array}$ & $\begin{array}{l}\text { — Ма дај йожури [већ } \\
\text { једном]! }\end{array}$ \\
\hline & & Наредба & — Ма дај крени [већ једном]! \\
\hline \multirow[t]{2}{*}{$\begin{array}{l}\text { Реактивни } \\
\text { исказ }\end{array}$} & Девалоризација & $\begin{array}{l}\text { Девалоризација } \\
\text { говорног чина } \\
\text { комплиментирања, } \\
\text { извињења и сл. }\end{array}$ & $\begin{array}{l}\text { — Ма дааај, иррекини! } \\
\text { — Ма дааај, заборави! }\end{array}$ \\
\hline & & & $\begin{array}{l}\text { Ma daj }+ \text { X1 [Pron.interrog] } \\
+ \text { Cop [V3.sg.fut] + X2 [Pron. } \\
\text { dat] + X3 [N/Pron1] }\end{array}$ \\
\hline
\end{tabular}




\begin{tabular}{|c|c|c|c|}
\hline \multirow[t]{3}{*}{$\begin{array}{c}\text { Тип } \\
\text { исказа }\end{array}$} & $\begin{array}{c}\text { Комуникативни } \\
\text { алгоритам }\end{array}$ & Прагматички контекст & $\begin{array}{c}\text { Синтаксички израз } \\
\text { и пример }\end{array}$ \\
\hline & & $\begin{array}{l}\text { Девалоризација } \\
\text { саговорникове намере }\end{array}$ & 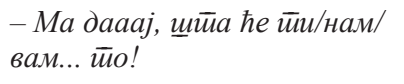 \\
\hline & & & $\begin{array}{l}\text { Мa дaj + X1 [Vimp]+ } \\
\text { X2 [Nacc]... }\end{array}$ \\
\hline \multirow[t]{3}{*}{$\begin{array}{l}\text { Иницијални } \\
\text { исказ }\end{array}$} & Подстицање & $\begin{array}{l}\text { Подстицање на } \\
\text { (имагинарни) чин. }\end{array}$ & — Ма дај обуци левисище! \\
\hline & & & $\begin{array}{l}\text { — Ма дај окрени йај } \\
\text { ринг̄ищйил у мојој г̄лави. }\end{array}$ \\
\hline & & & $\begin{array}{l}\text { Ma daj +X1 [V1.sg.prs] + } \\
\text { X2 [Pron2sg] }\end{array}$ \\
\hline \multirow[t]{3}{*}{$\begin{array}{l}\text { Реактивни } \\
\text { исказ }\end{array}$} & Подстицање & $\begin{array}{l}\text { Подстицање да се } \\
\text { нешто изврши у } \\
\text { саговорникову корист. }\end{array}$ & 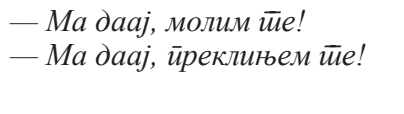 \\
\hline & & & $\begin{array}{l}\text { Ma daj }+ \text { X1 [Pron.interrog] + } \\
\text { X2 [Pron2/3] + X3 [V3.prs] }\end{array}$ \\
\hline & & & 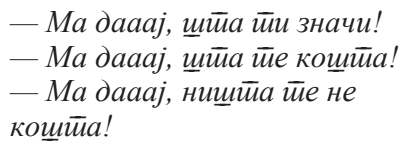 \\
\hline
\end{tabular}

Примећујемо да важну улогу у одређивању прагматичке изнијансираности комуникативне функције има акценат. Емфатички акценат, рецимо, у наведеним примерима јавља се само тада када је у питању девалоризација претходног исказа или подстицање да се нешто изврши у говорникову корист, уп.:

(19) «...ма даај, не закерај, види како је лейа йайуча, у стивари није.., ма

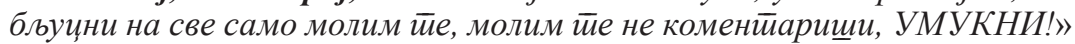
( $<$ https://milasila.rs/skrabanije/noge-smora/> 1.09.2021);

(20) «Добио сам йозив од йријайеља да идемо на демонстираиије... ја одг̄о-

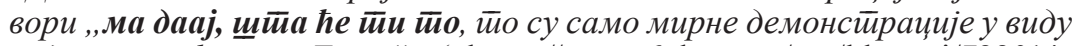
йодрикке грађанима Тузле“.») (<https://www.6yka.com/cyr/blogovi/722014hvala-na-pocetku>1.09.2021).

Прагматичка изнијансираност комуникативних формула посебно долази до изражаја у поређењу са средствима реализације одговарајућих функција у другим језицима. Ради илустрације упоредићемо комуникативни потенцијал српске формуле Ма дај! са формулом Да ну! у руском језику. У ту сврху користићемо фрагмент истраживања тима Ј. Рахилине (в. Рахилина 2019: 47: 25), који смо допунили неким додатно запаженим функцијама и примерима њихове реализације у разговорном језику (в. табелу 4). 
Комуникативна полифункционалност руске фразеологизоване формуле Да ну!

\begin{tabular}{|c|c|c|c|}
\hline $\begin{array}{c}\text { Тип } \\
\text { формуле }\end{array}$ & $\begin{array}{c}\text { Комуникативни } \\
\text { алгоритам }\end{array}$ & Прагматички контекст & Пример \\
\hline \multirow[t]{7}{*}{ Реактивна } & Изненађење & $\begin{array}{l}\text { Изненађење + } \\
\text { одушевљење }\end{array}$ & $\begin{array}{l}\text { - Снег пошел. } \\
\text { - Да ну! [Здорово!] }\end{array}$ \\
\hline & & Изненађење + неверица & $\begin{array}{l}\text { - Да нуууу! [Такого } \\
\text { не бывает!] }\end{array}$ \\
\hline & Девалоризација & $\begin{array}{l}\text { Девалоризација понуде } \\
\text { и одбијање да се она } \\
\text { прихвати }\end{array}$ & $\begin{array}{l}\text { - Пошли в столовую! } \\
\text { - Да ну! [Там невкусно.] }\end{array}$ \\
\hline & & $\begin{array}{l}\text { Девалоризација саговор- } \\
\text { ника као реакција на } \\
\text { његово понашање }\end{array}$ & $\begin{array}{l}\text { - Ты поесть приготовил? } \\
\text { - Нет. - Да ну! [Никогда } \\
\text { не приготовишь.] }\end{array}$ \\
\hline & & $\begin{array}{l}\text { Девалоризаија говорног } \\
\text { чина (комплиментирања, } \\
\text { извињења и сл.) }\end{array}$ & $\begin{array}{l}\text { - Какая у тебя } \\
\text { шапочка!. - Да ну! } \\
\text { [Десять лет ношу.] }\end{array}$ \\
\hline & Неслагање & $\begin{array}{l}\text { Неслагање са саговор- } \\
\text { никовом погрешном } \\
\text { претпоставком. }\end{array}$ & $\begin{array}{l}\text { - Не успеем! - Да ну! } \\
\text { Еще иельх } 3 \text { минутьы. }\end{array}$ \\
\hline & & $\begin{array}{l}\text { Неслагање } \\
\text { са саговорниковим } \\
\text { мишљењем. }\end{array}$ & $\begin{array}{l}\text { - У них много денег. } \\
\text { - Да нууу! [Ошибаешься.] }\end{array}$ \\
\hline
\end{tabular}

Табела 5

Комуникативни потенцијал синтаксичких фразеологизама са константом да ну у руском језику

\begin{tabular}{|c|c|c|c|}
\hline $\begin{array}{c}\text { Тип } \\
\text { исказа }\end{array}$ & $\begin{array}{c}\text { Комуникативни } \\
\text { алгоритам }\end{array}$ & Прагматички контекст & $\begin{array}{c}\text { Синтаксички израз } \\
\text { и пример }\end{array}$ \\
\hline & & & Да ну + X [Pron.subst]! \\
\hline \multirow{4}{*}{$\begin{array}{l}\text { Реактивни } \\
\text { исказ }\end{array}$} & Резигнација & Одустајање. & - Да ну их! \\
\hline & & Огорченост. & -Да ну вас [к черту]!! \\
\hline & Девалоризација & $\begin{array}{l}\text { Девалоризација } \\
\text { саговорниковог говорног } \\
\text { чина. }\end{array}$ & -Да ну тебя! \\
\hline & & & Да ну + X [Pron.adv]! \\
\hline $\begin{array}{l}\text { Реактивни } \\
\text { исказ }\end{array}$ & Недоумица & Недоумица + огорченост & $\begin{array}{l}\text { - Да ну зачем! } \\
\text { - Да нукак! } \\
\text { - Да ну где! }\end{array}$ \\
\hline
\end{tabular}

Упоредивши наведене примере из српског и руског језика, можемо закључити да се прагматички потенцијал фразеологизованих формула Ma даj! и Да ну!, као и конструкција у којима се ове формуле јављају у уло- 
зи константи, унеколико подудара, али и разликује. Највише сличности бележимо међу комуникативним функцијама фразеологизованих формула. Како Ма дај! тако и Да ну! могу изражавати изненађење, девалоризацију и неслагање (в. табеле 2 и 4), с тим што се у руском језику изненађење може изражавати без аксиолошке примесе, док се у српској говорној пракси уобичајено изражава изненађење у комбинацији са неверицом и разочарењем. Да би се изразило изненађење без примесе позитивне или негативне оцене, у српском језику се употребљава подеснија формула Ма немој!, чија прагматичка анализа следи даље.

Највише разлика пак уочавамо у прагматичкој структури фразеологизоване конструкције са константом ма дај и њеног аналога са константом да ну у руском језику. За разлику од руских конструкција, које су само реактивне природе, српске могу бити како реактивне тако и иницијалне (в. табеле 3 и 5). Помоћу српских фразеологизованих конструкција са константом ма дај могу се појачавати различите директивне илокуције (од молбе да се пожури са извршењем неког чина до молбе да се изврши чин у саговорникову корист), као и функција девалоризације саговорниковог говорног чина (нпр.: - Хвала йи до неба за оно. — Ма даај, иррекини!). У руском језику конструкције са константом да ну изражавају пре свега резигнацију или огорченост (- Я ещуе долго буду работать. - Да ну тебя! Пойду одна; - Новые соседи не пригласили нас к себе на вечеринку. - Да ну их! И без них проживем. ${ }^{7}$. У српском језику као еквивалент првог типа руске конструкције Да ну тебя! (у значењу одустајања) функционише фразеологизована формула $M a$ даj! (в. табелу 2), док се у другом случају, ради изражавања огорчености нечијим поступком, као еквивалент руских конструкција Да ну его!, Да ну их! и сл., намеће фразеологизована конструкција

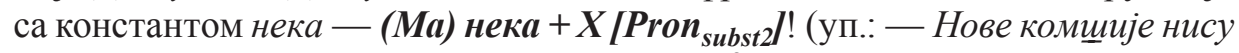
нас йозвали на своју журку. - Ма нека их! ${ }^{8}$ и сл.).

Још један пример комуникативно вишезначне фразеологизоване формуле у српском језику представља реактивни исказ Ма немој!, којим се може изразити чуђење (21), стрепња (22), али и прекор (23), односно девалоризација саговорниковог исказа (24) уп.:

(21) - Ана се удала.

— Ма немој! И никоме нищӣа није јавила!

7 Уп. такође пример у којем се тумачи једна од могућих комуникативних функција формуле Да ну их!: «Фактически, Янша прямым текстом написал «да ну их», подразумевая нежелательность приема большого количества беженцев из Афганистана, которые в Европе не желают интегрироваться в местное общество, сидят на пособиях и занимаются разного рода криминальной активностью» (Новости, 23.08.21).

8 У зависности од контекста српској фразеологизованој конструкцији Нека + $X\left[\right.$ Pron $\left._{\text {subs2 }}\right]$ ! одговара руска формула Hy и nycmb! или конструкција И поделом +

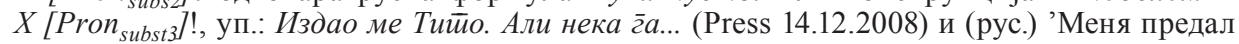

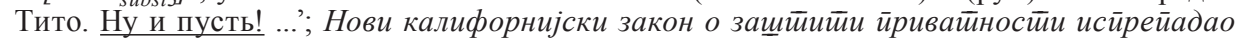
силицијумску долину. Нека је! (Journal on computing) и (рус.) 'Новый закон Калифорнии

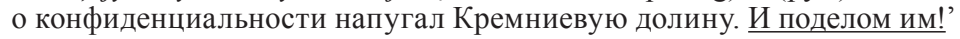


(22) - Може се деситии да ја одем у болнииу.

— Ма немој! Када?

(23) - Појела си сву чоколаду.

— Ма немој! А ко је јуче йојео све бомбоне?

(24) НУШИЋ: Она [слобода] ӣреба да буде свачија йо мало.

ГЕНЕРАЛ: Ма немој! Слобода је роба, сер. Јасно! (Теайрон 2018: 34)

Комуникативна вишезначност ове прагмеме посебно долази до изражаја приликом превођења на страни језик, где се исте функције могу изражавати различитим формулама. УП. горенаведене примере (21-24) са њиховим евентуалним преводним еквивалентима у руском језику (25-28):

(25) - Аня вышла замуж!

- Надо же! И никому ничего не сообщила!

(26) - Может случиться так, что мне придется лечь в больнииу.

- Да ну! Когда?

(27) - Ты съела весь шоколад.

— Кто бы говорил! А кто вчера съел все конфеты?

(28) НУШИЧ: Она [свобода] должна быть достоянием каждого.

ГЕНЕРАЛ: Только не надо! Свобода - это товар, сэр. Ясно!

Комуниктивна вишезначност представља одлику фразеологизованих формула у свим језицима, заправо ради се о дистинктивном обележју сваке комуникативне формуле, које је чини подесним средством за овладавање комуникативним минимумом страног језика ${ }^{9}$. Са друге стране, неколико фразеологизованих формула могу се објединити према типу прагматичне структуре у оквиру једне комуникативне функције или сличних функција. Рецимо, одговор на нечију молбу у српском језику може се изразити помоћу следећих комуникативних формула:

(29) Ма молим Вас!

(30) Нема ирроблема.

(31) У реду.

(32) Разуме се! и др.

9 Елочка Шчукина из романа И. Илфа и Е. Петрова 12 стиолица, као што је познато, имала је у свом комуникативном лексикону само 30 речи и конструкција помоћу којих се могла снаћи у свакој ситуацији. По правилу, овај пример се наводи као негативна карактеристика јунакиње, чије сиромаштво лексикона одсликава мањак духовних вредности. Међутим, с тачке гледишта овладавања комуникативним минимумом страног језика, идеја да се помоћу тридесетак фразеологизованих формула може снаћи у свакој могућој комуникативној ситуацији звучи примамљиво. Комуникативни фразеологизми из Елочкиног репертоара могли су изражавати, у зависности од случаја, иронију, изненађење, одушевљење, мржњу, радост, презир, задовољство, могли су се подједнако употребити приликом картања или у пословном разговору. Наведени пример из књижевности може послужити као илустрација полиилокутивности комуникативних фразеологизама. 
Наведене формуле се разликују с обзиром на изнијансираност прагмеме пристанка. Тако формула (29) сигналише да се говорно лице у потпуности слаже са саговорниковом молбом и да ће за њега испуњење молбе представљати неку врсту сатисфакције:

(33) - Да ли бистее мог̄ли да ме йовезеиее кад се будетее враћали за Беог̄рад? - Ма молим Вас. Биће ми задовољстиво.

Формуле (30) и (31) указују на говорникову спремност да поступи у складу са молбом која му се саопштава у некој врсти хијерархијске комуникације (говорно лице има право да захтева од саговорника да испуни његову молбу, најчешће се ради о претпостављеној особи или кориснику одређених услуга):

(34) - Молим Вас да йрег̃ледайе овај извещйај.

- Драг̄е воље! Послаћу Вам своју оцену тиоком идуће седмице.

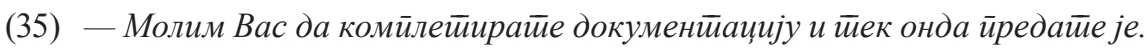
- У реду. Разумем. Урадићу йако.

Најзад, четврта формула (32) представља реактивни исказ помоћу којег се истиче да би чин у вези са којим је упућена молба био иначе реализован, тј. без саговорниковог посебног подсећања:

(36) - Дођи вечерас раније с йосла да не закаснимо у йозорищйе.

- Нема йроблема! Тако сам и намеравао.

Табела 6

Прагматичка изнијансираност фразеологизованих формула у оквиру комуникативне функције пристанка

\begin{tabular}{|c|c|c|c|}
\hline $\begin{array}{c}\text { Тип } \\
\text { формуле }\end{array}$ & Комуникативни алгоритам & Бенефицијар & Пример \\
\hline 1. & $\begin{array}{l}\text { Говорно лице у потпуности се слаже } \\
\text { са садржајем саговорникове молбе } \\
\text { и спремно је да поступи у складу са њом. }\end{array}$ & Саговорник & - Ма мооолим йе! \\
\hline 2. & $\begin{array}{l}\text { Говорник је спреман да поступи у } \\
\text { складу са захтевом који му се упућује } \\
\text { у асиметричној комуникацији }\end{array}$ & Саговорник & $\begin{array}{l}\text { - Драге воље! } \\
\text { - Уреду. } \\
\text { - Са задовољ- } \\
\text { сйвом! }\end{array}$ \\
\hline 3. & $\begin{array}{l}\text { Говорно лице истиче да би поступило } \\
\text { у складу са молбом и без } \\
\text { саговорниковог подсећања. }\end{array}$ & $\begin{array}{l}\text { Саговорник/ } \\
\text { Говорно лице }\end{array}$ & - Нема йроблема! \\
\hline
\end{tabular}

Примећујемо да приликом изражавања пристанка говорно лице заправо пристаје да реализује чин који може бити како у саговорниковом тако и у његовом, говорниковом, интересу. Од тога ко ће бити бенефицијар претпостављеног чина — говорник или саговорник такође зависи избор формуле. Уколико је бенефицијар само говорно лице, подеснија је употреба формуле 3. типа (в. Табелу 6), док би формуле 1. и 2. типа звучале необично, уп.: 
(37)

— Хоћещ ли сврайийи у самойослуг̄y?

— Нема ироблема! // ? Драгее воље! // ?? Ма мооолим йе!

Илокутивна изнијансираност формула у зависности од тога ко је вршилац а ко је бенефицијар радње још више долази до изражаја приликом одбијања (в. табелу 7).

Табела 7

Прагматичка изнијансираност фразеологизованих формула у оквиру комуникативне функције одбијања

\begin{tabular}{|c|c|c|c|c|}
\hline $\begin{array}{c}\text { Тип } \\
\text { формуле }\end{array}$ & $\begin{array}{c}\text { Комуникативни } \\
\text { алгоритам }\end{array}$ & Извршилац & Бенефицијар & Пример \\
\hline 1. & $\begin{array}{l}\text { Говорник одбија } \\
\text { да пристане } \\
\text { на саговорникову } \\
\text { понуду. }\end{array}$ & Саговорник & Говорник & — У редy je! \\
\hline 2. & $\begin{array}{l}\text { Говорник } \\
\text { одбија да допусти } \\
\text { да саговорник } \\
\text { поступи у складу } \\
\text { са својом молбом. }\end{array}$ & Саговорник & Саговорник & $\begin{array}{l}\text { - Не долази } \\
\text { у обзир! } \\
\text { - Ни йод раз! }\end{array}$ \\
\hline 3. & $\begin{array}{l}\text { Говорно лице одбија } \\
\text { да поступи у складу } \\
\text { са саговорниковом } \\
\text { молбом. }\end{array}$ & Говорно лице & $\begin{array}{l}\text { Саговорник/ } \\
\text { Говорно лице }\end{array}$ & 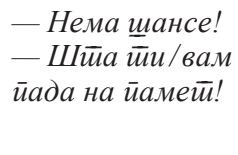 \\
\hline 4 & $\begin{array}{l}\text { Говорно лице одбија } \\
\text { да учествује } \\
\text { у извршењу чина који } \\
\text { предлаже } \\
\text { саговорник. }\end{array}$ & $\begin{array}{l}\text { Говорно лице + } \\
\text { Саговорник }\end{array}$ & $\begin{array}{l}\text { Говорно лице + } \\
\text { Саговорник }\end{array}$ & $\begin{array}{l}\text { — Не йада ми } \\
\text { на йамей! }\end{array}$ \\
\hline
\end{tabular}

Као пример употребе 1. типа комуникативне формуле за одбијање може послужити конверзација између купца и касира у продавници:

(37) КУПАЦ: Желииее ли можда да Вам дам сийно? КАСИР: У реду je!

Како наводи Ј. Рахилина, у руском језику не постоје дискурзивне формуле овог типа - за одбијање чина који врши саговорник у корист говорног лица (в. Табелу 7). Анализирајући енглеску формулу I'm okay! или I'm fine! у овом прагматичком контексту, научница наводи да једини сличан начин одбијања у руском језику представља употреба перформативне формуле: Нет, спасибо!, док адекватна комуникативна фразеологизована формула не постоји (Рахилина 2019: 45-51). Што се тиче српског језика, формула $У$ реду је! спада у разматрани тип одбијања, али није примерена ван тзв. дисталне комуникације. Тешко је замислити да неко на предлог да се почасти чоколадом узврати $У$ peдy je! док је енглеска комуникативна фор- 
мула I'm okay! апсолутно прихватљива у таквој ситуацији. Из тог угла српски и руски су слични када је у питању изражавање интенције одбијања, јер би и у српском језику једини примерен одговор у наведеној ситуацији био: Не могуу, хвала!

Оваква изнијансираност фразеологизованих формула у оквиру једног комуникативног алгоритма наглашава неопходност њиховог пажљивог проучавања и типологије.

J. Рахилина заснива своју типологију дискурзивних формула на њиховим комуникативним функцијама, које сматра водећим критеријумом. Тако, у руском језику научница издваја 8 основних типова функција и за сваки од њих одређује по 7 најфреквентнијих формула. Према резултатима пилот истраживања које је њен тим спровео, издвојени су седам основних типова дискурзивних формула, које у руском језику чине искази, груписани у оквиру следећих комуникативних функција:

1) Изненађење (Ничего себе! Надо же!)

2) Индиферентност (Нет так нет! Мне то что!)

3) Захтевање да се понови информација (Это как? В каком смысле?)

4) Неслагање (Не скажи! Ничего подобного!)

5) Одбијање (Ни за что! Вот еще!)

6) Потврђивање (И не говори! А то!)

7) Пристајање (Не вопрос! Я за!)

8) Исказивање саговорникове оцене (Эх mы!! И ты туда же!) (Рахилина 2019: 39:02).

У српском језику такође можемо издвојити наведене комуникативне функције, које у овом раду посматрамо као комуникативне алгоритме, као и неке друге, уп:

1) Допуштање (Па хаајде. Нек му буде.)

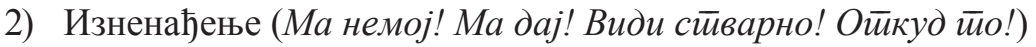

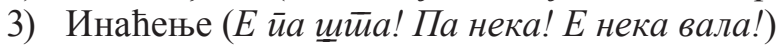

4) Индиферентност (Како тии кажещ. Нема везе!)

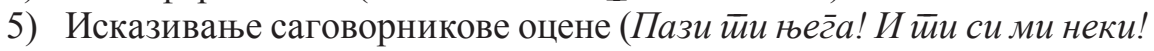
Ко си йa $\bar{u} u !)$

6) Захтев за понављањем информације (Како тио мислищ? Како йо? Како сад?)

7) Метаисказ (Да йако кажем. Да скрайим йричу. Једном речју.)

8) Најава (Кажи драгиччка!)

9) Неслагање (Како да не! Није нег̄o! Е вала није!)

10) Одбијање (Ма каквих! (Ма) Нема щансе! (Ма) Ни йод раз! Не долази у обзир.)

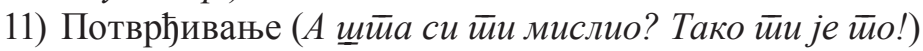

12) Пристанак (Није ироблем! Нема ироблема! Како да не! Ја сам за! У реду.)

13) Повлађивање (Ма у реду је! Ма није йроблем!) 
14) Прекоравање (За име бог̄a! Аман за аман! Докле с йим? Тако ӣи бог̄a!)

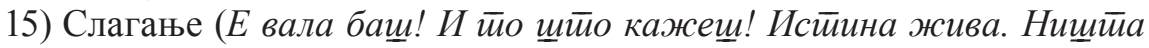
jа. Па да! Како не!)

У оквиру једног комуникативног алгоритма исказе диференцирамо с обзиром на саговорников иницијални исказ. На пример, у случају исказивања изненађења у српском језику могу се употребити следеће комуникативне формуле:

(39) Ма немој!

(40) Ma даj!

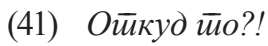

(42) Види сварно! и др.

Формуле (39) и (40) представљају реакцију на исказ који предочава нову чињеницу, која се међутим не дотиче саговорника директно, нпр.:

(43) - Комиија је куйио нов ауйо.

- Ма немој! Лейо.

Формуле (40), (41) јављају се као реакција на исказ који се доживљава са неверицом јер, по правилу, садржи информацију која није пријатна по саговорника, нпр.:

(44) - Пала сам на исииийу.

— Ма дај! Не могуу да верујем.// Ойкуд йо?! Па учила си све време.

Последња у низу наведених формула (42), по правилу, представља реакцију на предочену ситуацију у коју се саговорник може и сам уверити, нпр.:

(45) - Кищиа йада.

-Види сииварно! Нисам ни йримейио.

\section{7. Закључак}

На основу извршене анализе долазимо да закључка да су комуникативни фразеологизми веома распрострањени у савременом српском језику и углавном представљају савремену тенденцију у њему, с обзиром да се већина њих не јавља до друге половине 20. века ${ }^{10}$.

Комуникативне формуле заједно са синтаксичким фразеологизмима често се групишу око једног прагматичког језгра, те се из структурног аспекта могу посматрати у оквиру прагматичке парадигме. Језгро парадигме представљају константе чија прагматичка валентност одређује број и облик променљивих у фразеологизованим синтаксичким конструкцијама. Прагматичке структурне шеме синтаксичких фразеологизама разликују се

10 В. наслове прегледаних драмских дела у списку извора. 
од језика до језика и представљају фрагмент одређене језичке слике света, која се може интерпретирати с ослонцем на унутрашњу форму прагматичког

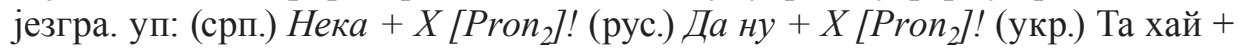
$X\left[\mathrm{Pron}_{3}\right]+\bar{z}$ реиьь! итд.

Односе између комуникативне формуле и синтаксичког фразеологизма можемо посматрати као екстерне трансформације у оквиру прагматичке парадигме, док односе између варијаната синтаксичких фразеологизама са различитим променљивим и истим константама одређујемо као интерне модификације унутар прагматичке парадигме. Приликом екстерне трансформације долази до промене комуникативног алгоритма унутар којег се примењује фразема, док модификације са истом константом не надилазе један комуникативни алгоритам. Комуникативне формуле представљају исказе са највишим експресивно-прагматичким напоном унутар парадигме, који настају као резултат постепене редукције синтаксичког фразеологизма и његовог свођења на најлаконичнији израз.

\section{Односи у оквиру йраг̄майичке йарадиг̄ме}

Екстерне трансформације: синтаксички фразеологизам $\rightarrow$ комуникативна формула

(срп.) Ма дај иррекини! $\rightarrow$ Ма дај!

(рус.) Да ну тебя! $\rightarrow$ Дану!

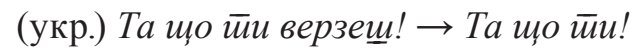

Интерне модификације: између синтаксичких фразеологизама са истом константом

(срп.) Ма дај йрекини! // Ма дај заборави! // Ма дај йомози! итд.

(рус.) Да ну тебя // Да ну его! // Да ну вас! // Да ну их всех! итд.

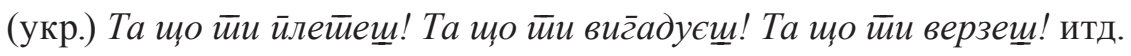

Комуникативни фразеологизми приликом анализе морају се разматрати с обзиром на конкретне комуникативне алгоритме, под којима се подразумева устаљени скуп прагматичких правила и услова чије испуњење води задовољењу комуникативног циља.

Понуђена методологија описа комуникативних формула види се као прикладна за опис синтаксичких идиома у српском језику у оквиру ширег истраживања. Извршена анализа основних типова комуникативних кластера ослања се на примере из десетак драмских текстова, као и на забележене примере из разговорног језика, док би исцрпни опис „српског конструктикона“ захтевао анализу већег броја текстова, која би обухватила и опис одговарајућих интонационих конструкција и гестова. Такво истраживање би могло резултирати формирањем одговарајуће банке комуникативних формула, које би се могле претраживати како према типу комуникативног алгоритма тако и према регистру идиоматизованих исказа. Други корак у истраживању представљало би трагање за еквивалентима српских 
комуникативних формула у другим језицима, уз навођење одговарајућих примера из паралелних корпуса и, пожељно, опис гестикулације и интонационих конструкција у сваком од језика. Такво комплексно истраживање могло би бити остварено у оквиру већег научноистраживачког пројекта у чијој реализацији би свакако били заинтересовани сви коме је стало до проучавања савремених тенденција у језику.

\section{ЛИТЕРАТУРА}

Апресян Юрий Д. Избранные труды. Т. 1. Лексическая семантика: синонимические средства языка. Москва: Языки русской культуры, 1995.

Бахтин Михаил. Эстетика словесного творчества. Москва: Искусство, 1979.

Иорданская Лидия Н., Мельчук Игорь А. Смысл и сочетаемость в словаре. Москва: Языки славянских культур, 2007.

Копотев М. В., Стексова Т. И. Исключение как правило: Переходные единицы в грамматике и словаре. Москва: Языки славянской культуры, 2016.

Мельчук Игорь А. «Об одном классе фразеологических сочетаний. (Описание лексической сочетаемости с помощью семантических параметров)». Архангельский В. Л. (отв. ред.). Проблемы устойчивости и вариативности фразеологических единиц. Материаль межвузовского симпозиума. Тула: Тульский государственнй педагогический институт им. Л. Н. Толстого, 1968: 51-65.

Мельчук Игорь А. Курс общеей морфологии. T. IV. Москва — Вена, 2001.

Николаева Татьяна М. Функции частии в выскказывании. Москва: Наука, 1985.

Поповић Људмила. „Комуникативне функције просте реченице“. Пипер П., Антонић И., Ружић В., Танасић С., Поповић Љ., Тошовић Б. Синйакса савременог̄a срӣског̄ језика.

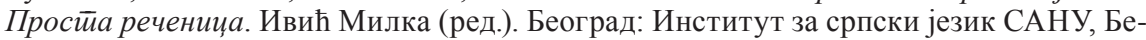
оградска књига, Матица српска, 2005.

Поповић Људмила. „О актуелним когнитивнолингвистичким проучавањима српског језика“. Јужнословенски филолог̄ 73/3-4 (2017): 315-354.

Рахилина Екатерина В. (ред.) Лингвистика конструкций. Москва: Азбуковник, 2010.

Рахилина Екатерина В. О дискурсивных формулах. [Лекция]. Москва: Отделение теоретической и прикладной лингвистики МГУ, 8.05.2019. <https://www.youtube.com/ watch? $\mathrm{v}=\mathrm{jUUJ}$ Jmilqy0 $>1.09 .2021$.

Шведова Нина Ю. (гл. ред.). Русская грамматика. Т. ІІ. Синтаксис. Институт русского языка АНССР, Москва: Наука, 1980.

Austin John L. How to Do Things with Words: The William James Lectures delivered at Harvard University in 1955. Urmson J. O. and Sbisà Marina (eds.). Oxford: Clarendon Press, 1962.

Bybee Joan. "Cognitive Processes in Grammaticalization". Tomasello M. (ed.) The New Psychology of Language. Cognitive and Functional Approaches to Language Structure. V. 2. Mahwah, New Jersey - London, 2003: 145-167.

Brinton Laurel J., Traugot Elisabeth Closs. Lexicalization and Language Change. Cambridge: CUP, 2005.

Croft William. Radical Construction Grammar. Syntactic Theory in Typological Perspective. Oxford: Oxford Univesity Press, 2002

Fillmore Charles J. "The mechanisms of 'Constraction Grammar". Proceedings of the Fourteenth Annual Meeting of the Berkeley Linguistics Society. 1988: 35-55.

Fillmore Charles J., Kay Paul. Construction Grammar Coursebook. Berkeley: University of California at Department of linguistics, 1993.

Fillmore Charles J., Kay Paul. "Grammatical Constructions and Linguistic Generalizations: The What's X doing Y? Construction". Language 75/1 (1999): 1-33.

Fried Mirjam, Ostman Jan-Ola (eds.). Construction Grammar in a cross-language perspective. Amsterdam: John Benjamins, 2004.

Jackendoff Ray.”The Boundaries of the Lexicon", Martin Everaert, Erik-Jan van der Linden, Andre Schenk, Rob Schreuder (eds.). Idioms: Structural and Psychological Perspectives. Hillsdale, New Jersey, Hove: Erl-baum, 1995: 133-165. 
Kay Paul. An Informal Sketch of a Formal Architecture for Construction Grammar. <www.icsi. berkeley.edu/ kay/cg.arch.ps.> 1.09.2021.

Kuryłowycz Jerzy. "The evolution of grammatical categories". Diogenes 51 (1965): 55-71.

Kuteva Tania, Heine Berndt. "An integrative model of grammaticalisation". Wiemer Björn, Wälchli Bernhard, Hansen Björn (eds.). Grammatical Replication and Borrowability in Language Contact. Berlin — Boston: Mouton de Gruyter, 2012: 159-190

Lakoff George. Women, Fire, and Dangerous Things: what Categories Reveal about the Mind. Chicago-London: University of Chicago Press, 1987.

Lakoff George, Johnson Mark. Metaphors we live by. Chicago: University of Chicago Press, 1980.

Langlotz Andreas. Idiomatic Creativity: A cognitive-linguistic model of idiom-representation and idiom-variation in English. Amsterdam/Philadelphia: John Benjamins, 2006.

Langacker Ronald W. Foundations of cognitive grammar. Vol. 1-2. Stanford: Stanford University Press, 1987.

Langacker Ronald W. "A usage-based model”. Rudzka-Ostyn Brygida (ed). Topics in Cognitive Linguistics. Amsterdam: Benjamins, 1988: 127-161.

Meillet Antoine. "L'evolution des formes grammaticales". Scientia (Rivista di scienza) 12 (1912): 384-400.

Searl John. Speech Acts: An Essay in the Philosophy of Language. Cambridge University Press, 1969.

Skok Petar. Etimološki rječnik hrvatskoga ili srpskoga jezika. T. 2. Zagreb: JAZU, 1972.

\section{REFERENCES}

Apresyan Yurij D. Izbrannye trudy. T. 1. Leksicheskaya semantika: sinonimicheskie sredstva yazyka. Moskva: Yazyki russkoj kul'tury, 1995.

Bahtin Mihail. Estetika slovesnogo tvorchestva. Moskva: Iskusstvo, 1979.

Iordanskaya Lidiya N., Mel'chuk Igor' A. Smysl i sochetaemost'v slovare. Moskva, Yazyki slavyanskih kul'tur, 2007.

Kopotev M. V., Steksova T. I. Isklyuchenie kak pravilo: Perehodnye edinicy v grammatike i slovare. Moskva: Yazyki slavyanskoj kul'tury, 2016.

Mel'chuk Igor' A. «Ob odnom klasse frazeologicheskih sochetanij. (Opisanie leksicheskoj sochetaemosti s pomoshch'yu semanticheskih parametrov)». Arhangel'skij V. L. (otv. red.). Problemy ustojchivosti i variativnosti frazeologicheskih edinic. Materialy mezhvuzovskogo simpoziuma. Tula: Tul'skij gosudarstvennyj pedagogicheskij institut im. L. N. Tolstogo, 1968: 51-65.

Mel'chuk Igor' A. Kurs obshshej morfologii. T. IV. Moskva - Vena, 2001.

Nikolaeva Tat'yana M. Funkcii chastic v vyskazyvanii. Moskva: Nauka, 1985.

Popović Ljudmila. „Komunikativne funkcije proste rečenice“. Piper P., Antonić I., Ružić V., Tanasić S., Popović Lj., Tošović B. Sintaksa savremenoga srpskog jezika. Prosta rečenica. Ivić Milka (red.). Beograd: Institut za srpski jezik SANU, Beogradska knjiga, Matica srpska, 2005.

Popović Ljudmila. „O aktuelnim kognitivnolingvističkim proučavanjima srpskog jezika“. Južnoslovenski filolog 73/3-4 (2017): 315-354.

Rahilina Ekaterina V. (red.) Lingvistika konstrukcij. Moskva: Azbukovnik, 2010.

Rahilina Ekaterina V. O diskursivnyh formulah. [Lekcis]. Moskva: Otdelenie teoreticheskoj i prikladnoj lingvistiki MGU, 8.05.2019. <https://www.youtube.com/watch?v=jUUJmnilqy0> 1.09.2021.

Shvedova Nina Yu. (gl. red.). Russkaya grammatika. T. II. Sintaksis. Institut russkogo yazyka ANSSR, Moskva: Nauka, 1980.

Austin John L. How to Do Things with Words: The William James Lectures delivered at Harvard University in 1955. Urmson J. O. and Sbisà Marina (eds.). Oxford: Clarendon Press, 1962.

Brinton Laurel J., Traugot Elisabeth Closs. Lexicalization and Language Change. Cambridge: CUP, 2005.

Croft William. Radical Construction Grammar. Syntactic Theory in Typological Perspective. Oxford: OUP, 2002. 
Fillmore Charles J. “The mechanisms of 'Constraction Grammar". Proceedings of the Fourteenth Annual Meeting of the Berkeley Linguistics Society. 1988: 35-55.

Fillmore Charles J., Kay Paul. Construction Grammar Coursebook. Berkeley: University of California at Department of linguistics, 1993.

Fillmore Charles J., Kay Paul. "Grammatical Constructions and Linguistic Generalizations: The What's X doing Y? Construction”. Language 75/1 (1999): 1-33.

Fried Mirjam, Ostman Jan-Ola (eds.). Construction Grammar in a cross-language perspective. Amsterdam: John Benjamins, 2004.

Jackendoff Ray."The Boundaries of the Lexicon”, Martin Everaert, Erik-Jan van der Linden, Andre Schenk, Rob Schreuder (eds.). Idioms: Structural and Psychological Perspectives. Hillsdale, New Jersey, Hove: Erl-baum, 1995: 133-165.

Kay Paul. An Informal Sketch of a Formal Architecture for Construction Grammar. <www.icsi. berkeley.edu/ kay/cg.arch.ps.> 1.09.2021.

Kuryłowycz Jerzy. "The evolution of grammatical categories". Diogenes 51 (1965): 55-71.

Kuteva Tania, Heine Berndt. "An integrative model of grammaticalisation". Wiemer Björn, Wälchli Bernhard, Hansen Björn (eds.). Grammatical Replication and Borrowability in Language Contact. Berlin/Boston: Mouton de Gruyter, 2012: 159-190

Lakoff George. Women, Fire, and Dangerous Things: what Categories Reveal about the Mind. Chicago-London: University of Chicago Press, 1987.

Lakoff George, Johnson Mark. Metaphors we live by. Chicago: University of Chicago Press, 1980.

Langlotz Andreas. Idiomatic Creativity: A cognitive-linguistic model of idiom-representation and idiom-variation in English. Amsterdam/Philadelphia: John Benjamins, 2006.

Langacker Ronald W. Foundations of cognitive grammar. Vol. 1-2. Stanford: Stanford University Press, 1987.

Langacker Ronald W. "A usage-based model”. Rudzka-Ostyn Brygida (ed). Topics in Cognitive Linguistics. Amsterdam: Benjamins, 1988: 127-161.

Meillet Antoine. "L'evolution des formes grammaticales". Scientia (Rivista di scienza) 12 (1912): 384-400.

Searl John. Speech Acts: An Essay in the Philosophy of Language. Cambridge University Press, 1969.

Skok Petar. Etimološki rječnik hrvatskoga ili srpskoga jezika. T. 2. Zagreb: JAZU, 1972.

\section{ИЗВОРИ}

Гајовић Александар. Први срйски йајкун. Колико исииина сачињава једну лаж $<$ https://klubglasnik.com/> 01.09.2021.

Вранеш Стеван. Сведобро. Теайрон 176-177 (2016): 5-31.

Илић Миодраг. Арлекинова последња авантура. Теайрон 184-185, (2018): 7-45

Новости, 23.08.2021

$<$ https://ren.tv/news/v-mire/871999-da-nu-ikh-chinovniki-evrosoiuza-vdryzg-razrugalisiz-za-bezhentsev> 28.08.2021

Нушић Бранислав. Покојник.

$<$ https://www.rastko.rs/drama/nusic/bnusic-pokojnik.html $>01.09 .2021$.

Петровић Растко. О расйущйеностии бог̄ова $<$ http://www.svevlad.org.rs/bajoslovlje/knjizevnost/petrovic_perun.html $>01.09 .2021$.

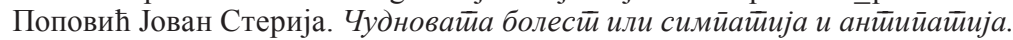
$<$ https://www.rastko.rs/drama/delo/12994> 01.09.2021.

Поповић Јован Стерија. Зла жена. $<$ https://sr.m.wikisource.org/sr> 01.09.2021.

Симовић Љубомир. Чудо у „Шарг̄ану“. $<$ http://biblioteka-np.org.rs/wpcontent/uploads/2020/05/Cudo_u_Sarganu.pdf $>$ 01.09.2021.

Стевановић Тихомир. Кандило у розаријуму. <file://C:/Users/Emil/Downloads/3941-Article\%20Text-8312-1-10-20171204.pdf> 01.09.2021. 
Трифковић Коста. Избирачица.

$<\mathrm{http} / / /$ biblioteka-np.org.rs/> 01.09.2021.

Journal on computing.

$<$ https://raf.edu.rs/en/eraf-journal-on-computing/archive-scientific-papers/item/5512-

uljevi-robert> 1.09.2021

Nezavisne novine.

$<$ https:/www.nezavisne.com/magazin/zanimljivosti/Da-li-znate-Zasto-se-kaze-Kazidragicka/420168>1.09.2021.

Press 14.12.2008.

$<$ http://www.27mart.com/main.php?pages_id=240\&languages_id=2>1.09.2021

\section{SOURCES}

Gajović Aleksandar. Prvi srpski tajkun. Koliko istina sačinjava jednu laž $<$ https://klubglasnik.com/> 01.09.2021.

Vraneš Stevan. Svedobro. Teatron 176-177 (2016): 5-31.

Ilić Miodrag. Arlekinova poslednja avantura. Teatron 184-185 (2018): 7-45

Novosti, 23.08.2021. $<$ https://ren.tv/news/v-mire/871999-da-nu-ikh-chinovniki-evrosoiuza-vdryzg-razrugalisiz-za-bezhentsev> 28.08.2021

Nušić Branislav. Pokojnik. $<$ https://www.rastko.rs/drama/nusic/bnusic-pokojnik.html> 01.09.2021.

Petrović Rastko. O raspuštenosti bogova. $<$ http://www.svevlad.org.rs/bajoslovlje/knjizevnost/petrovic_perun.html $>01.09 .2021$.

Popović Jovan Sterija. Čudnovata bolest ili simpatija i antipatija. $<$ https://www.rastko.rs/drama/delo/12994>01.09.2021.

Popović Jovan Sterija. Zla žena. $<$ https://sr.m.wikisource.org/sr> 01.09.2021.

Simović Ljubomir. Čudo u „Šarganu“. $<$ http://bibliotekanp.org.rs/wpcontent/uploads/2020/05/Cudo_u_Sarganu.pdf > 01.09.2021.

Stevanović Tihomir. Kandilo u rozarijumu. <file:///C:/Users/Emil/Downloads/3941-Article Text-8312-1-10-20171204.pdf> 01.09.2021.

Trifković Kosta. Izbiračica. $<$ http://biblioteka-np.org.rs/> 01.09.2021.

Journal on computing $<$ https://raf.edu.rs/en/eraf-journal-on-computing/archive-scientific-papers/item/5512uljevi-robert> 1.09.2021

Nezavisne novine. $<$ https://www.nezavisne.com/magazin/zanimljivosti/Da-li-znate-Zasto-sekaze-Kazi-dragicka/420168> 1.09.2021.

Press 14.12.2008.

$<$ http://www.27mart.com/main.php?pages_id=240\&languages_id=2>1.09.2021

\section{Людмила Попович}

\section{КОММУНИКАТИВНЫЕ ФОРМУЛЫ В СЕРБСКОМ ЯЗЫКЕ: ВОПРОСЫ ТИПОЛОГИИ И АНАЛИЗА}

Резюме

В работе, впервые в сербской лингвистике, рассматриваются некоторые теоретические вопросы исследования коммуникативных фразеологизмов, к числу которых зачислены синтаксические фразеологизированные конструкции и коммуникативные формулы. 
Исходя из понятия коммуникативного алгоритма, под которым подразумевается устойчивый набор прагматических правил, ведущих к постижению коммуникативной цели, определяются условия употребления конкретных коммуникативных формул.

Постулируется понятие прагматической парадигмы, которую составляют фразеологизированные синтаксические конструкции и коммуникативные формулы, сгруппированные вокруг одного конструктивного ядра. Ядро парадигмы представлено константами, прагматическая валентность которых определяет количество и форму переменных во фразеологизированных синтаксических конструкциях. Структурные схемы прагматического уровня различаются от языка к языку и представляют собой фрагмент определенной языковой картины мира, который можно интерпретировать исходя из внутренней формы

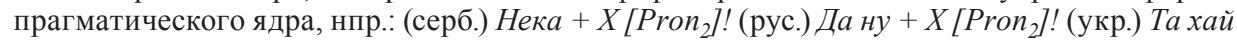

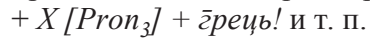

Отношения между дискурсивной формулой и синтаксической фразеологизированной конструкцией рассматриваются как внешние преобразования коммуникативных фразеологизмов, в то время как отношения между вариантами синтаксических фразеологизмов с разными переменными и одинаковыми константами определяются как внутренние модификации. При внешнем преобразовании происходит изменение типа коммуникативного алгоритма, которым определяется выбор фразы, а при отношении модификации конструкции функционируют в рамках одного коммуникативного алгоритма.

Дискурсивные формулы интерпретируются как высказывания с наивысшим экспрессивно-прагматическим напряжением в рамках парадигмы, которые возникают в результате постепенного сокращения синтаксических фразеологизмов и их сворачивания до максимально лаконичного выражения, обладающего самым высоким экспрессивным потенциалом.

Исходя из конкретного языкового материала делается вывод о широкой распространенности дискурсивных формул в сербском языке, что оценивается как современная тенденция, поскольку их примеры не встречаются в текстах конца XIX - начала XX веков. В статье рассмотрены конкретные дискурсивные формулы в сравнении с аналогичными примерами из восточнославянских языков. Сделан вывод о том, что предложенные методы анализа можно применять при составлении банка коммуникативных конструкций в сербском языке.

Ключевые слова: коммуникативные формулы, синтаксические фразеологизмы (фраземы), прагматикализация, прагматическая парадигма, сербский язык. 